\title{
Neutral, closed-shell nickel bis(2-alkylthio-thiazole-4,5-dithiolate) complexes as single component molecular conductors $\dagger$
}

Hadi Hachem, ${ }^{a}$ Zijun Xu, ${ }^{a}$ Nathalie Bellec, ${ }^{a}$ Olivier Jeannin, ${ }^{a}$ Pascale AubanSenzier, ${ }^{b}$ Thierry Guizouarn, ${ }^{a}$ Marc Fourmigué ${ }^{\star a}$ and Dominique Lorcy ${ }^{\star a}$

${ }^{a}$ Univ Rennes, CNRS, ISCR (Institut des Sciences Chimiques de Rennes) - UMR 6226, F35000 Rennes, France. E-mail: marc.fourmigue@univ-rennes1.fr;dominique.lorcy@univrennes1.fr

${ }^{b}$ Laboratoire de Physique des Solides UMR 8502 CNRS-Université de Paris-Sud, Bat 510, 91405 Orsay cedex, France

Dominique Lorcy: https://orcid.org/0000-0002-7698-8452

Marc Fourmigué: https://orcid.org/0000-0002-3796-4802

$†$ Electronic supplementary information (ESI) available: Tables S1 and S2 and Figures S1-S7. X-ray data are available in CIF format. CCDC 1826889-1826894. For ESI and crystallographic data in CIF format see DOI: 10.1039/XXXXX

\section{Abstract}

Neutral nickel bis(dithiolene) complexes, because of their closed-shell character, are usually considered as insulating materials, unless they are formed out of highly delocalized tetrathiafulvalenedithiolate ligands. We describe here an original series of S-alkyl substituted neutral bis(thiazole-4,5-dithiolate) nickel complexes formulated as [Ni(RS-tzdt)2] $(\mathrm{R}=\mathrm{Me}, \mathrm{Et})$, which organize in the solid state into uniform stacks and exhibit a semiconducting behavior, with room temperature conductivities comparable to those reported in the prototypical [Ni(dmit)2] and [Ni(Et-thiazdt)2] neutral complexes. These findings provide new perspectives in the current search for single component molecular conductors. 


\section{Introduction}

For a couple of decades, nickel bis(dithiolene) complexes have been intensively studied as precursors of multicomponent molecular conductors in mixed-valence salts, ${ }^{1,2}$ especially after the discovery of the first superconducting material $(\mathrm{TTF})\left[\mathrm{Ni}(\mathrm{dmit})_{2}\right]_{2}(\mathrm{dmit}=2$-thioxo-1,3dithiole-4,5-dithiolate). ${ }^{3}$ Subsequently, various modifications of the dithiolate ligand skeleton have been performed providing a whole library of mixed valence salts. ${ }^{1 b}$ More recently, coordination polymeric materials involving nickel bis(dithiolene) complexes were also described as highly conducting $\pi$-nanosheets. ${ }^{4}$ Despite the formally closed-shell nature of these nickel complexes, another emerging strategy consists in using these complexes directly as single component molecular conductors, that is a neutral complex without any counterion. ${ }^{5}$ Highly conducting neutral nickel bis(dithiolene) complexes bearing a non-innocent tetrathiafulvalene (TTF) backbone were successfully reported by Kobayashi et al. ${ }^{6,7,8}$ So far, only two other examples of neutral Ni complexes lacking this TTF backbone were reported to behave as single component molecular conductor, namely the neutral $\mathrm{Ni}(\mathrm{dmit})_{2}$ itself $^{9}$ and $\left[\mathrm{Ni}(\text { Et-thiazdt })_{2}\right]^{10}{ }^{10}$ The latter $\left[\mathrm{Ni}(\text { Et-thiazdt })_{2}\right]$ complex exhibits under ambient conditions a

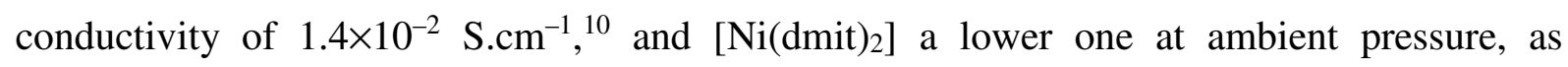
described by Cassoux $\left(\sigma_{\mathrm{RT}}=3.5 \times 10^{-3}{\mathrm{~S} . \mathrm{cm}^{-1}}^{-1 \mathrm{a}}\right.$ or Kato $\left(\sigma_{\mathrm{RT}}=6 \times 10^{-2} \mathrm{~S} \mathrm{~cm}^{-1}, \mathrm{E}_{\text {act }}=0.14\right.$ $\mathrm{eV}){ }^{9 \mathrm{~b}}$ Furthermore, under very high pressure (above $15.9 \mathrm{GPa}$ ), [Ni(dmit) $)_{2}$ was shown to become metallic, the pressure increasing the band dispersion up to a point where the semiconducting gap closes. ${ }^{9 \mathrm{~b}}$ Other weakly conducting neutral $\mathrm{Ni}$ complexes have been also reported but, due to the lack of strong intermolecular interactions between these complexes in the solid state, the values of conductivity are much lower (from $10^{-11}$ to $10^{-6} \mathrm{~S} \mathrm{~cm}^{-1}$ ). ${ }^{11}$ Indeed, due to their closed-shell character, these neutral nickel complexes behave as classical band semiconductors, their conductivity is essentially tuned by the size of the gap and the gap is controlled by the extend of the overlap interactions between complexes. Decreasing this gap can be performed under pressure but can be also attempted by modifying the chemical structure of the complexes, favoring an extended electronic delocalization while maintaining planarity, as detailed here.

We have indeed recently evidenced an unprecedented transformation of N-tert-butyl1,3-thiazoline-2-thione heterocycles into 2-alkylthiothiazole derivatives in the presence of electrophiles. ${ }^{12}$ This reactivity opened the way to a series of novel dithiolate ligands, the 2alkylthio-1,3-thiazole-4,5-ditholate (RS-tzdt) (Chart 1). The radical gold complexes [Au(RS$\left.\mathrm{tzdt}_{2}\right] \bullet$ were subsequently prepared from the oxidation of the monoanionic $\mathrm{Au}^{\mathrm{III}}$ complexes , 
and shown to organize into slightly dimerized conducting chains. ${ }^{12 a}$ Here, we explore the corresponding neutral but closed-shell nickel complexes [Ni(RS-tzdt $\left.)_{2}\right]$ and investigate their structural and electronic properties, also in comparison with their $\mathrm{N}$-alkyl analogues $[\mathrm{Ni}(\mathrm{R}-$ thiazdt $\left.)_{2}\right](\mathrm{R}=\mathrm{Et}, \mathrm{Me})$.

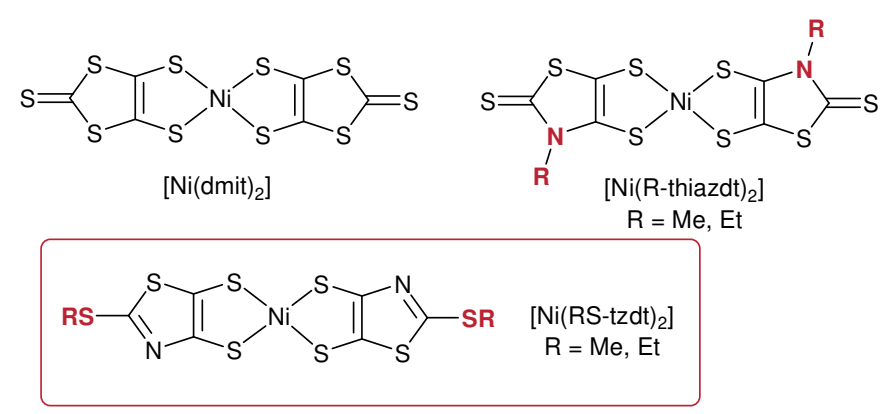

Chart 1 Chemical structures of investigated neutral nickel bis(dithiolene) complexes.

\section{Results and Discussion}

\section{Syntheses}

Two different approaches can be used to synthesize the Ni bis(dithiolene) complexes, [Ni(RStzdt) 2 ] $(\mathrm{R}=\mathrm{Me}, \mathrm{Et})$. The main route (Route a in Scheme 1) involves the protected form of the dithiolene ligands as starting material, that is the 2-alkylthio-1,3-thiazoles $\mathbf{2 a - b}$, obtained from the $\mathrm{N}$-tBu-1,3-thiazoline-2-thione $\mathbf{1}$ as described earlier. ${ }^{12}$ Deprotection of $\mathbf{2 a - b}$ to the dithiolate ligand in basic medium using $\mathrm{NaOMe}$ followed by the addition of $\mathrm{NiCl}_{2} \cdot 6 \mathrm{H}_{2} \mathrm{O}$ and $\mathrm{PPh}_{4} \mathrm{Br}$ leads to the formation of the dianionic Ni complexes formulated $\left[\mathrm{PPh}_{4}\right]_{2}[\mathrm{Ni}(\mathrm{RS}-$ tzdt $)_{2}$ ]. Attempts to characterize these dianionic complexes were unsuccessful as these dianionic species are easily oxidized to the paramagnetic radical anion species (see below). For instance, recrystallization of the complexes upon air atmosphere afforded the crystalline monoanionic corresponding complexes $\left[\mathrm{PPh}_{4}\right]\left[\mathrm{Ni}(\mathrm{RS}-\mathrm{tzdt})_{2}\right](\mathrm{R}=\mathrm{Me}, \mathrm{R}=\mathrm{Et})$. The neutral complexes $\left[\mathrm{Ni}(\mathrm{RS}-\mathrm{tzdt})_{2}\right]$ are then obtained by electrocrystallization of the monoanionic complexes and are collected as tiny black crystals at the anode. Note that both trans and cis isomers of the monoanionic and neutral complexes might be obtained in solution, albeit only the trans isomers were isolated in the solid state (see below). 


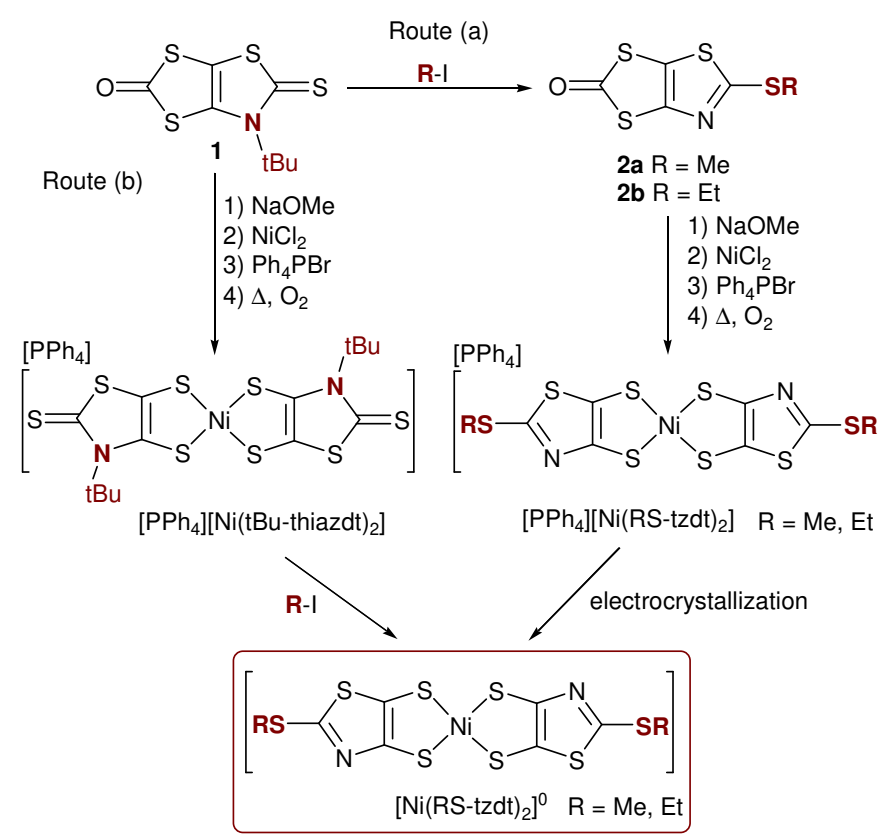

Scheme 1 Synthetic routes toward the neutral nickel complexes [Ni(RS-tzdt $\left.)_{2}\right]$

The second approach (Route $\mathrm{b}$ in Scheme 1) uses the $\mathrm{N}$-tBu complex, $\left[\mathrm{PPh}_{4}\right][\mathrm{Ni}(t \mathrm{Bu}-$ thiazdt) 2 , which was prepared from $\mathrm{N}-\mathrm{tBu}$-1,3-thiazoline-2-thione 1, the protected form of the dithiolene ligand. ${ }^{12}$ The monoanionic $\left[\mathrm{PPh}_{4}\right]\left[\mathrm{Ni}(t \mathrm{Bu} \text {-thiazdt })_{2}\right]$ complex was synthetized according to the same procedure as the one used for the $\left[\mathrm{Ph}_{4} \mathrm{P}\right]\left[\mathrm{Ni}(\mathrm{RS} \text {-tzdt })_{2}\right]$ complexes. Then we attempted the chemical transformation of the ligand on the Ni complex. This was performed by refluxing $\left[\mathrm{PPh}_{4}\right]\left[\mathrm{Ni}(t \mathrm{Bu} \text {-thiazdt })_{2}\right]$ in the presence of either iodomethane or iodoethane. Nonetheless using these conditions we did not isolate the corresponding monoanionic complexes but rather the neutral species [Ni(MeS-tzdt $)_{2}$ ]. In the case of iodomethane, we converted $\left[\mathrm{PPh}_{4}\right]\left[\mathrm{Ni}(t \mathrm{Bu}-\text { thiazdt })_{2}\right]$ into the neutral $\left[\mathrm{Ni}(\mathrm{MeS}-\mathrm{tzdt})_{2}\right]$ in $64 \%$ yield, while with iodoethane, the neutral $\left[\mathrm{Ni}(\mathrm{EtS}-\mathrm{tzdt})_{2}\right]$ complex was obtained with a very low yield 5\%. This difference was certainly due in part to the reactivity of iodomethane compared to iodoethane and also to the lower solubility of [Ni(MeS-tzdt $\left.)_{2}\right]$ versus [Ni(EtS$\operatorname{tzdt})_{2}$, since the former precipitated easily into the reaction mixture.

\section{Electrochemical properties}

Cyclic voltammetry (CV) investigations were carried out on the monoanionic species in $\mathrm{CH}_{2} \mathrm{Cl}_{2}$ using $\mathrm{NBu}_{4} \mathrm{PF}_{6}$ as supporting electrolyte. The redox potentials are collected in Table 1 together with those of the $\mathrm{N}$-substituted complexes [Ni(R-thiazdt $\left.)_{2}\right](\mathrm{R}=\mathrm{Me}, \mathrm{Et})$ for comparison purposes. For the investigated complexes, three oxidation processes are observed. The two first ones are well defined except for the S-Me complex (Figure 1) where the second 
process is not fully reversible, due to adsorption phenomena on the electrode. They correspond to the successive electron transfer between the dianionic species into the radical anion and then to the neutral species. The third oxidation process, ascribed to the oxidation of the neutral complex into the monocationic species, is, comparatively, of lesser intensity presumably due to a decomposition of the neutral complex upon oxidation.

Table 1 Redox potentials of the [Ni(RS-tzdt $\left.)_{2}\right](R=M e, E t)$ and $\left[\mathrm{Ni}(\mathrm{R} \text {-thiazdt })_{2}\right](\mathrm{R}=\mathrm{Me}$, Et, $\mathrm{tBu})$ complexes, in $\mathrm{V}$ vs SCE, in $\mathrm{CH}_{2} \mathrm{Cl}_{2}$ with $0.1 \mathrm{M} \mathrm{Bu}_{4} \mathrm{NPF}_{6}$, scan rate $100 \mathrm{mV} . \mathrm{s}^{-1}$.

\begin{tabular}{lcccc}
\hline & $\mathrm{E}^{1}$ & $\mathrm{E}^{2}$ & $\Delta \mathrm{E}=\mathrm{E}^{2}-\mathrm{E}^{1}$ & $\mathrm{E}_{\mathrm{pa}}{ }^{3} / \mathrm{E}_{\mathrm{pc}}{ }^{3}$ \\
\hline$\left[\mathrm{Ni}(\mathrm{MeS}-t z d t)_{2}\right]$ & -0.48 & $0.20 / 0.03^{\mathrm{a}}$ & 0.65 & $1.16 / 1.02$ \\
{$\left[\mathrm{Ni}(\text { EtS-tzdt })_{2}\right]$} & -0.48 & 0.16 & 0.64 & $1.25 /-$ \\
& & & & \\
{$\left[\mathrm{Ni}(t \mathrm{Bu}-\text { thiazdt })_{2}\right]$} & -0.43 & 0.13 & 0.56 & $0.96 / 0.83$ \\
{$\left[\mathrm{Ni}(\mathrm{Me}-\text { thiazdt })_{2}\right]$} & -0.34 & $0.22 / 0.00^{\mathrm{a}}$ & - & \\
{$\left[\mathrm{Ni}(\text { Et-thiazdt })_{2}\right]$} & -0.37 & 0.17 & 0.54 & 1.12 \\
\hline
\end{tabular}

${ }^{\mathrm{a}} \mathrm{E}_{\mathrm{pa}} / \mathrm{E}_{\mathrm{pc}}$ : anodic and cathodic peak potentials

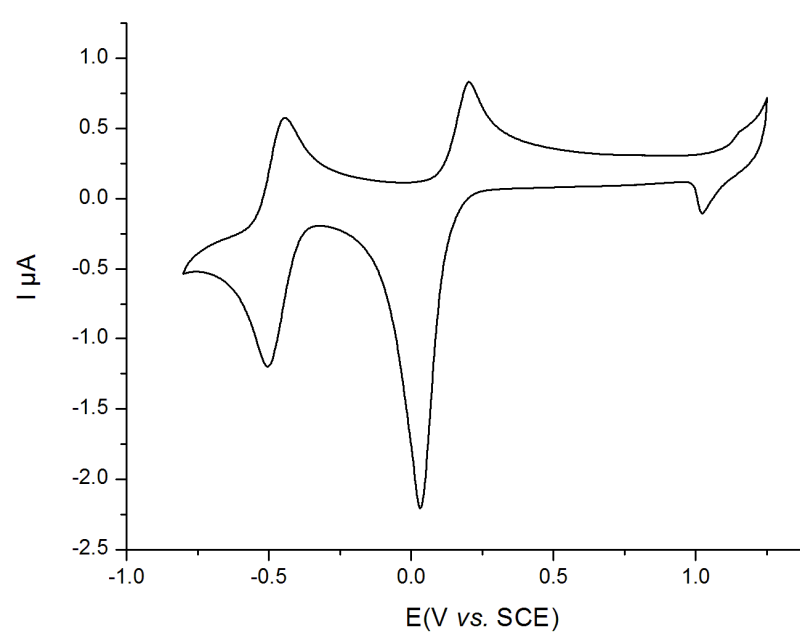

Fig. 1 Cyclic voltammogram of $\left[\mathrm{Ph}_{4} \mathrm{P}\right]\left[\mathrm{Ni}(\mathrm{MeS} \text {-tzdt) })_{2}\right.$ in $\mathrm{CH}_{2} \mathrm{Cl}_{2}$ containing $\mathrm{NBu}_{4} \mathrm{PF}_{6} 0.1 \mathrm{M}$, scan rate $100 \mathrm{mV} \mathrm{s}^{-1}$.

Comparison of the redox potentials (Table 1) shows that the novel S-substituted dianionic complexes are easier to oxidize into the anion radical species than their N-substituted analogues. It demonstrates that the 2-alkylthio-1,3-thiazole core acts as a stronger electron donating group than the N-alkyl-1,3-thiazole-2-thione ring. Moreover, the effect of the alkyl 
substituent on the nitrogen atom of the thiazoline ring exercises also a significant effect as the presence of the $\mathrm{tBu}$ group shifts the oxidation potentials by $90 \mathrm{mV}$ compared to the N-Me. Then for all the complexes the second process corresponding to the oxidation of the anion radical complexes to the neutral one occurs at similar potentials independently of the nature of the ligand. As a consequence, the stability window of the radical anion species, represented by the difference $\Delta E=E^{2}-E^{1}$, is larger for the novel S-substituted complexes than for the Nsubstituted ones.

\section{UV-vis-NIR spectroelectrochemical investigations}

Radical anion and neutral nickel dithiolene complexes are known to exhibit strong absorptions in the near infra-red region (NIR), as also observed here. The absorption properties of the radical anion species, were first measured in $\mathrm{CH}_{2} \mathrm{Cl}_{2}$ at room temperature and corresponding maximum absorption wavelengths and absorption coefficients are collected in Table 2. Due to the low solubility of the neutral species, only maximum absorption wavelengths determined thanks to spectro-electrochemical investigations are given in Table 2. UV-vis-NIR spectro-electrochemical investigations (Figure 2) were carried out on the anion radical species in $\mathrm{CH}_{2} \mathrm{Cl}_{2}$ with $\mathrm{NBu}_{4} \mathrm{PF}_{6}$ as supporting electrolyte. All the investigated complexes exhibit a low energy band in the NIR region at 1228-1284 $\mathrm{nm}$ for the $\mathrm{N}$-substituted complexes and at $1080 \mathrm{~nm}$ for the S-substituted complexes. Upon gradual oxidation to the neutral species, this low energy band decreases together with the gradual growth of a new absorption band at higher energies around $1020 \mathrm{~nm}$ for the $\mathrm{N}$-alkyl and 910 $\mathrm{nm}$ for the $\mathrm{S}$ alkyl substituted complexes.

The main observation is a notable blue shift exhibited by the S-substituted complexes, both in the radical anion form as in the neutral state, when compared with the N-substituted complexes. This evolution is easily rationalized for the monoanionic complexes as it parallels the evolution of the $\Delta \mathrm{E}=\mathrm{E}^{2}-\mathrm{E}^{1}$ redox potentials. It appears therefore that the aromaticity of the thiazole ring in the S-substituted complexes limits the extent of delocalization within the complexes, due to $\pi$-electron confinement on the aromatic ring, a well-known phenomenon in conducting polymers. ${ }^{13}$ 


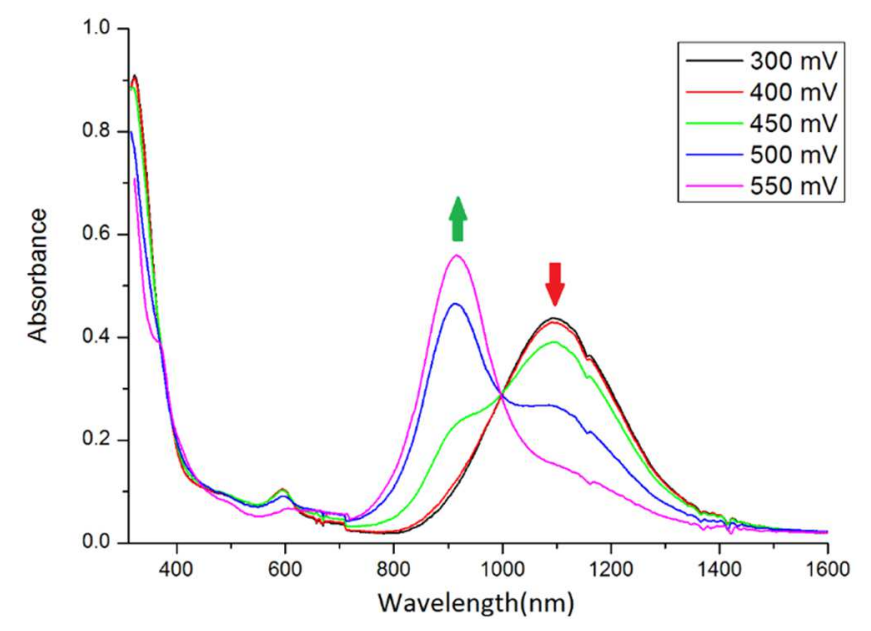

Fig. 2 UV-vis NIR monitoring of the electrochemical oxidation of [PPh $[\text { [Ni(MeS-tzdt) })_{2}$ in $\mathrm{CH}_{2} \mathrm{Cl}_{2}$ with $\mathrm{NBu}_{4} \mathrm{PF}_{6} 0.2 \mathrm{M}$ as supporting electrolyte from $0.0 \mathrm{~V}$ to $0.55 \mathrm{~V}$.

Table 2 Absorption maxima $\lambda_{\max }(\mathrm{nm})$ and molar extinction coefficient $\varepsilon\left(\mathrm{M}^{-1} \mathrm{~cm}^{-1}\right)$ for the NIR absorptions. Values for the neutral complexes were obtained from the spectroelectrochemical investigations (No $\varepsilon$ values are reported).

\begin{tabular}{llc}
\hline & $\lambda_{\max } \mathrm{nm}\left(\varepsilon \mathrm{M}^{-1} \mathrm{~cm}^{-1}\right)$ \\
\hline & anion radical & neutral \\
\hline$\left[\mathrm{Ni}(\mathrm{MeS}-t z d t)_{2}\right]$ & $1084(15400)$ & 908 \\
{$\left[\mathrm{Ni}(\text { EtS-tzdt })_{2}\right]$} & $1076(13250)$ & 918 \\
& & \\
{$\left[\mathrm{Ni}(t \mathrm{Bu}-\mathrm{thiazdt})_{2}\right]$} & $1228(22900)$ & 1036 \\
{$\left[\mathrm{Ni}(\text { Et-thiazdt })_{2}\right]$} & $1280(31000)$ & 1022 \\
{$\left[\mathrm{Ni}(\mathrm{Me}-\mathrm{thiazdt})_{2}\right]$} & $1284(29080)$ & 1013 \\
\hline
\end{tabular}

\section{The monoanionic complexes: solid state properties}

The three monoanionic complexes isolated here, that is the starting $\mathrm{N}$-tBu derivative $\left[\mathrm{PPh}_{4}\right]\left[\mathrm{Ni}(t \mathrm{Bu} \text {-thiazdt })_{2}\right]$ and the two S-substituted ones, $\left[\mathrm{Ph}_{4} \mathrm{P}\right]\left[\mathrm{Ni}(\mathrm{RS}-\mathrm{tzdt})_{2}\right],(\mathrm{R}=\mathrm{Me}, \mathrm{Et})$ were characterized by single crystal X-ray diffraction. $\left[\mathrm{PPh}_{4}\right]\left[\mathrm{Ni}(t \mathrm{Bu}-\text { thiazdt })_{2}\right]$ was found to crystallize either alone or as toluene solvate. Both crystallize in the monoclinic system, space group $\mathrm{C} 2 / \mathrm{c}$, with the $\mathrm{PPh}_{4}{ }^{+}$cation on a two-fold axis and the dithiolene complex on inversion center (as also the toluene molecule in the solvate). Intramolecular bond distances and angles compare with those reported for monoanionic nickel complexes with other substituents $[R=$ $\mathrm{Me}, \mathrm{Et}, \mathrm{CH}(\mathrm{Me}) \mathrm{Ph}]$ on the nitrogen atom (See Table S1 in ESI). ${ }^{10,14}$ In the solvent-free 
structure, the outer $\mathrm{C}=\mathrm{S}$ moiety of the complex are disordered on two positions, one with $25 \%$ occupancy essentially in the molecular plane, one with $75 \%$ occupancy bringing the sulfur atom out of the molecular plane by $0.75(2) \AA$. A projection view of the unit cell of the solvent-free $\left[\mathrm{PPh}_{4}\right]\left[\mathrm{Ni}(t \mathrm{Bu}-\text { thiazdt })_{2}\right]$ salt (Fig. 3) shows that the radical anions are well separated from each other in the $(a c)$ plane by the bulky $\mathrm{PPh}_{4}{ }^{+}$cations. A similar structure is found in the solvate salt, with toluene molecules pushing apart from each other the radical anions. (See Fig. S1 in ESI). Intermolecular S••^S contacts along the $b$ direction exceed 3.61 $\AA$ A. Magnetic susceptibility measurements performed on the non-solvated compound confirm its paramagnetic behavior, with a temperature evolution well fitted by a Curie-Weiss law of weakly interacting $S=1 / 2$ species $(\theta=-0.74(1) \mathrm{K})$ (Fig. S2 in ESI).

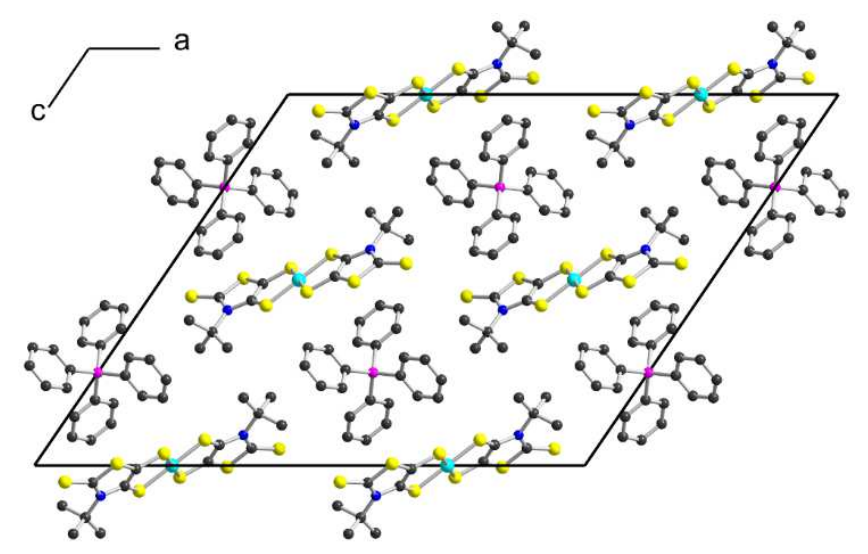

Fig. 3 Projection view of the unit cell of the solvent-free $\left[\mathrm{PPh}_{4}\right]\left[\mathrm{Ni}(t \mathrm{Bu} \text {-thiazdt })_{2}\right]$ salt. Only the majority component of the disordered $\mathrm{C}=\mathrm{S}$ moieties is shown (See text).

Concerning the S-substituted anionic complexes, they both also crystallize in the monoclinic system, space group $\mathrm{C} 2 / \mathrm{c}$ with the $\mathrm{PPh}_{4}{ }^{+}$cation on a two-fold axis and the complex anion on inversion center. Intramolecular bond distances are collected in Table 3. Intramolecular distances within the metallacycles compare with those described for other nickel dithiolene complexes (see Table S1). Note also that the SMe substituent in [Ni(MeStzdt $\left.)_{2}\right]^{1-}$ lies in the molecular plane (Fig 4a) while the ethyl group in $\left[\mathrm{Ni}(\mathrm{EtS}-\mathrm{tzdt})_{2}\right]^{1-}$ is found out of the molecular plane, disordered on two equiprobable (50:50) positions (Fig. 4b). Both complexes are not isostructural with the analogous gold complexes $\left[\mathrm{Ph}_{4} \mathrm{P}\right]\left[\mathrm{Au}(\mathrm{RS}-\mathrm{tzdt})_{2}\right](\mathrm{R}=$ $\mathrm{Me}, \mathrm{Et})$ described earlier. ${ }^{12 \mathrm{a}}$ In the latter indeed, the anionic dithiolene complexes were not located on inversion centers, a consequence of a different orientation of the alkyl groups on both sides of the complexes. 


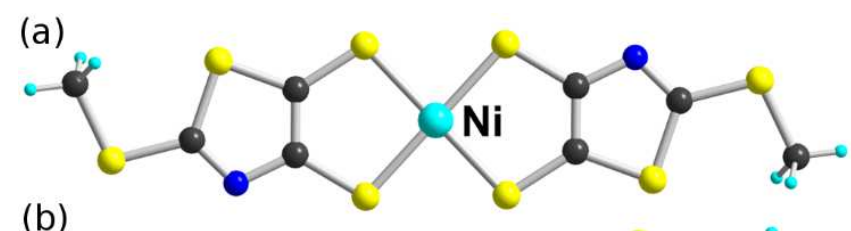

(b)

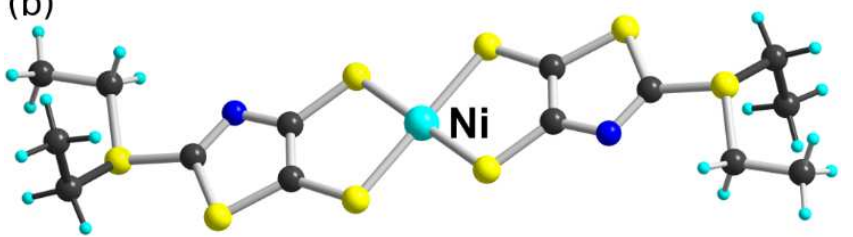

Fig. 4 Molecular structure of the two S-substituted complex anions, (a) [Ni(MeS-tzdt) $]^{1-}$, (b) $[\mathrm{Ni}(\mathrm{EtS}-$ tzdt) $\left.{ }_{2}\right]^{1-}$ in their $\mathrm{PPh}_{4}{ }^{+}$salt. In the latter, the two disordered orientations of the ethyl group are shown with different bond color.

Table 3 Bond distances within the anionic and neutral

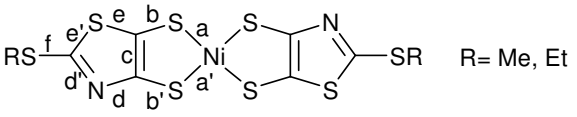
complexes $\left[\mathrm{Ni}(\mathrm{RS} \text {-tzdt) }]^{1-,}, 0\right.$.

\begin{tabular}{lllllll}
\hline Complex & $\mathrm{Ni-S}\left(\mathrm{a}, \mathrm{a}^{\prime}\right)$ & $\mathrm{S}-\mathrm{C}\left(\mathrm{b}, \mathrm{b}^{\prime}\right)$ & $\mathrm{C}=\mathrm{C}(\mathrm{c})$ & $\mathrm{C}-\mathrm{N}\left(\mathrm{d}, \mathrm{d}^{\prime}\right)$ & $\mathrm{C}-\mathrm{S}\left(\mathrm{e}, \mathrm{e}^{\prime}\right)$ & $\mathrm{C}-\mathrm{SR}(\mathrm{f})$ \\
\hline$\left[\mathrm{Ni}(\mathrm{MeS}-\mathrm{tzdt})_{2}\right]^{-}$ & $2.162(8)$ & $1.715(5)$ & $1.346(6)$ & $1.380(6)$ & $1.726(3)$ & $1.741(6)$ \\
& $2.166(3)$ & $1.722(4)$ & & $1.297(6)$ & $1.745(4)$ & \\
{$\left[\mathrm{Ni}(\mathrm{EtS}-\mathrm{tzdt})_{2}\right]^{-}$} & $2.175(4)$ & $1.718(4)$ & $1.377(5)$ & $1.376(5)$ & $1.741(3)$ & $1.747(5)$ \\
& $2.164(3)$ & $1.730(3)$ & & $1.296(6)$ & $1.761(4)$ & \\
{$\left[\mathrm{Ni}(\mathrm{MeS}-\mathrm{tzdt})_{2}\right]^{0}$} & $2.145(4)$ & $1.683(6)$ & $1.408(9)$ & $1.385(8)$ & $1.727(7)$ & $1.743(7)$ \\
& $2.163(2)$ & $1.700(7)$ & & $1.282(9)$ & $1.758(7)$ & \\
{$\left[\mathrm{Ni}(\mathrm{EtS}-\mathrm{tzdt})_{2}\right]^{0}$} & $2.149(3)$ & $1.687(2)$ & $1.407(4)$ & $1.377(3)$ & $1.723(3)$ & $1.733(3)$ \\
& $2.164(2)$ & $1.703(3)$ & & $1.314(3)$ & $1.758(4)$ & \\
\hline
\end{tabular}

In $\left[\mathrm{PPh}_{4}\right]\left[\mathrm{Ni}(\mathrm{MeS} \text {-tzdt })_{2}\right]$, the radical anions organize into layers (Fig. S3) separated from each other by the $\mathrm{PPh}_{4}{ }^{+}$cations, with long intermolecular S•••S contacts exceeding $3.80 \AA$. The temperature dependence of the magnetic susceptibility (Fig. S4) exhibits a smooth maximum at $34 \mathrm{~K}$ reflecting the presence of weak antiferromagnetic interactions. It is well fitted with a uniform $\operatorname{spin} S=1 / 2$ chain model ${ }^{15}$ with a temperature independent contribution $\chi_{0}$ $=5.3 \times 10^{-3} \mathrm{~cm}^{3} \mathrm{~mol}^{-1}$ and $\mathrm{J} / \mathrm{k}=-44.4(2) \mathrm{K}$. The justification for this spin chain behavior can be found back to the actual organization of the $\left[\mathrm{Ni}(\mathrm{MeS}-\mathrm{tzdt})_{2}\right]^{1-}$ radical anions within the 
layers. As shown in Fig. 5, each radical interacts sideways along the $a+b$ and $a-b$ directions, with two different overlap patterns (Fig 5b). Calculations of the interactions energies between radicals gives $\left|\beta_{1}\right|=0.1323 \mathrm{eV}$ and $\left|\beta_{2}\right|=0.054 \mathrm{eV}$ for the two overlap patterns. Since the $J_{1} / J_{2}$ ratio writes as $\left(\beta_{1} / \beta_{2}\right)^{2}=6.4$, the fit with the uniform spin chain model can provide a reasonable agreement for the strongest interaction within chains running parallel to $a+b$ (in red in Fig. 5)

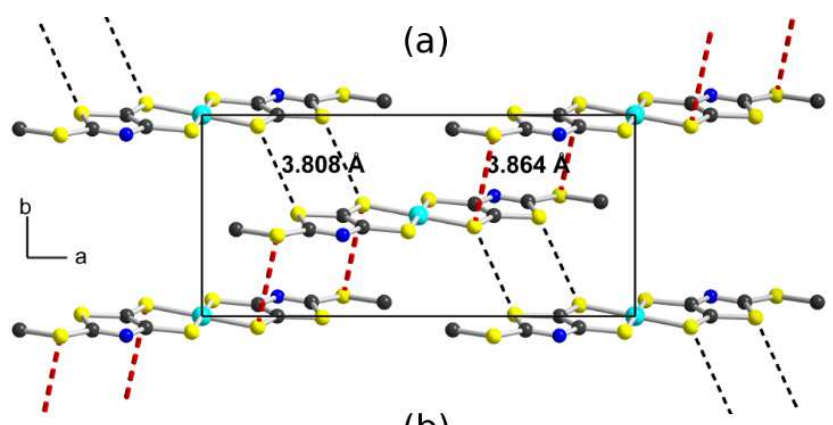

(b)

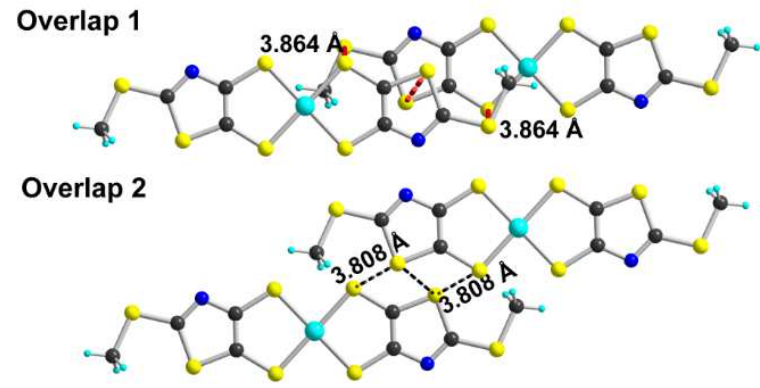

Fig. 5 Detail of the overlap interactions within the layers formed by the $[\mathrm{Ni}(\mathrm{MeS}-\mathrm{tzdt})]^{1-}$ radicals.

The situation is also complex in the ethyl analog, $\left[\mathrm{PPh}_{4}\right]\left[\mathrm{Ni}(\mathrm{EtS}-\mathrm{tzdt})_{2}\right]$, where the radical anions interact with neighboring complexes (Fig. S5) through one single, short intermolecular S $\bullet \bullet S$ contact at 3.823(2) $\AA$ which connects the radical species into a 2D network in the (bc) plane. This interaction is associated with a calculated $\beta$ interaction energy of $-0.027 \mathrm{eV}$. The temperature dependence of the magnetic susceptibility exhibits a smooth maximum at $52 \mathrm{~K}$. However, attempts to fit the data with a $S=1 / 2$ Heisenberg spin square lattice were not satisfactory, ${ }^{16}$ at variance with a $S=1 / 2$ Heisenberg uniform spin chain model with $\chi_{0}=$ $3.1 \times 10^{-4} \mathrm{~cm}^{3} \mathrm{~mol}^{-1}$ and $J / \mathrm{k}=-75.6(1) \mathrm{K}$ (Fig. S6).

\section{The neutral complexes and their solid state properties.}

$\left[\mathrm{Ni}(\mathrm{MeS}-\mathrm{tzdt})_{2}\right]^{0}$ crystallizes in the monoclinic system, space group $\mathrm{P} 21 / \mathrm{n}$, while $[\mathrm{Ni}(\mathrm{EtS}-$ tzdt $\left.)_{2}\right]^{0}$ crystallizes in the triclinic system, space group $P \overline{1}$, with the neutral complexes located on inversion centers in both compounds. Bond distances collected in Table 3 confirm the 
expected trends recurrently observed between anionic and neutral oxidized complexes in these series within the $\mathrm{NiS}_{2} \mathrm{C}_{2}$ metallacycles, i.e. a shortening of the $\mathrm{C}-\mathrm{S}$ bonds and a lengthening of the $\mathrm{C}=\mathrm{C}$ bonds. The methyl and ethyl substituents are ordered and located in the molecular plane. In the solid state, both complexes are organized into stacks interacting sideways to generate two-dimensional structures (Fig. 6). Note also in $\left[\mathrm{Ni}(\mathrm{MeS}-\mathrm{tzdt})_{2}\right]^{0}$ an intermolecular $\mathrm{S} \cdot \bullet \mathrm{N}$ contact at 3.598(6) $\AA$ between the sulfur atom of the thiometyl group and the heterocyclic nitrogen atom of a neighboring slab connecting thus crystallographically equivalent layers along the $b$ axis. Albeit larger than the sum of the van der Waals radii of $\mathrm{S}$ and $\mathrm{N}\left(3.35 \AA\right.$ ), this contact could contribute to give $\left[\mathrm{Ni}(\mathrm{MeS}-\mathrm{tzdt})_{2}\right]^{0}$ a $3 \mathrm{D}$ character.

(a)
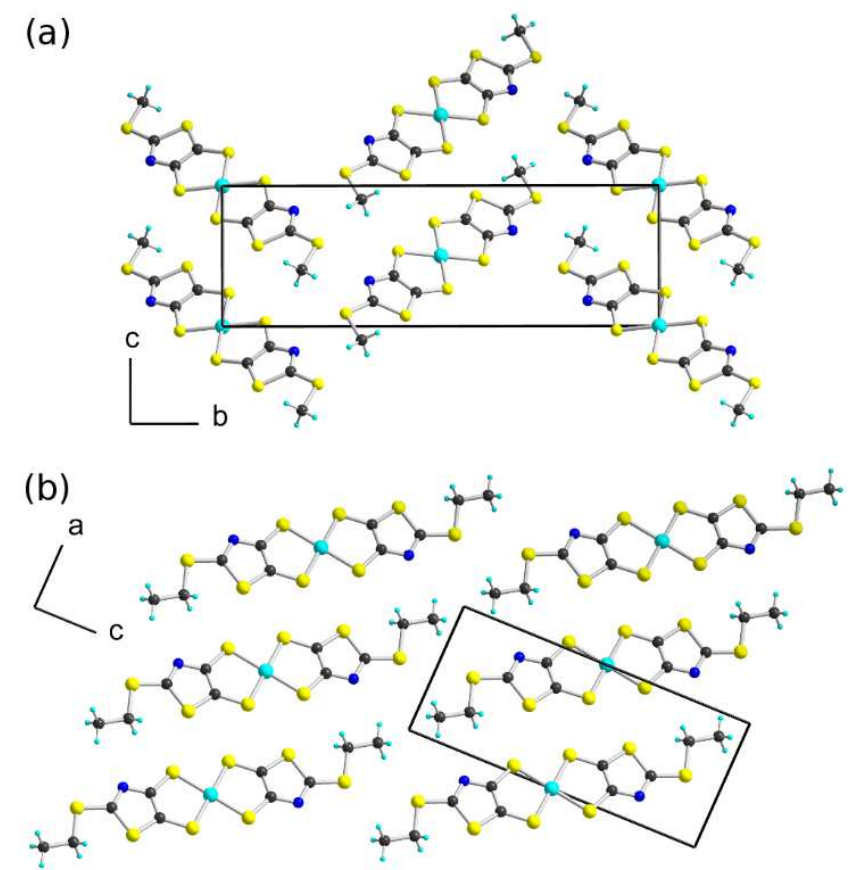

Fig. 6 Projection views of the unit cells of (a) [Ni(MeS-tzdt) $)_{2}$, (b) [Ni(EtS-tzdt) $)_{2}$.

The resistivity measurements were performed in two points either with or without gold pads and the measured resistivities are influenced by the type of procedure used. The room temperature conductivity at ambient pressure, $\sigma_{\mathrm{RT}}(1 \mathrm{bar})$ lies in the range $5 \times 10^{-7}$ to $5 \times 10^{-6}$ S.cm ${ }^{-1}$ for the $\left[\mathrm{Ni}(\mathrm{MeS}-\mathrm{tzdt})_{2}\right]^{0}$ complex, and $10^{-5}$ to $10^{-4} \mathrm{~S} . \mathrm{cm}^{-1}$ for $\left[\mathrm{Ni}(\mathrm{EtS}-\mathrm{tzdt})_{2}\right]^{0}$ complex. This large range can be explained by taking into account the uncertainty on the geometrical factor between resistance and resistivity and the ill-defined current lines in a 2D material. The temperature dependence of the conductivity (Fig. S7) shows that both complexes behave as semiconductors with activation energies of respectively $0.31 \mathrm{eV}(0.30 \mathrm{eV})$ and $0.30 \mathrm{eV}(0.24$ 
$\mathrm{eV})$ for the $\left[\mathrm{Ni}(\mathrm{MeS}-\mathrm{tzdt})_{2}\right]^{0}$ and $\left[\mathrm{Ni}(\mathrm{EtS}-\mathrm{tzdt})_{2}\right]^{0}$ complexes respectively with gold pads (without gold pads).

To rationalize the transport properties of both complexes and their differences, the extend and dimensionality of the interactions between the nickel complexes have been

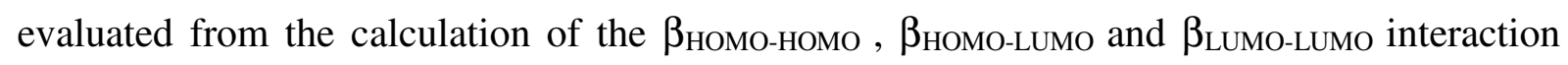
energies (Table S2) for the three interactions shown in Fig. 7. Strong interactions are found within the stacks (Interaction I), but also between the stacks (interactions II, III), giving the compound a potentially $2 \mathrm{D}$ electronic character. In $\left[\mathrm{Ni}(\mathrm{MeS}-\mathrm{tzdt})_{2}\right]$, the calculated $\beta$ values associated with the $\mathrm{S} \bullet \bullet \mathrm{N}$ contacts between layers, along $b$ (see above) are all very weak (< $0.02 \mathrm{eV})$.
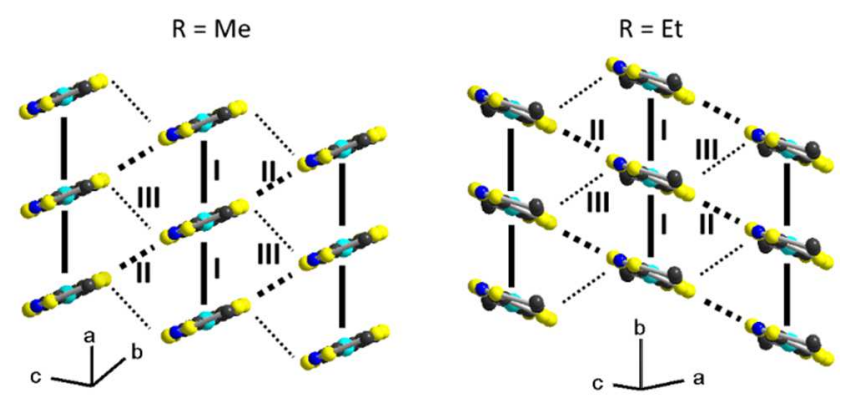

Fig. 7 Side views of the conducting slabs of $\left[\mathrm{Ni}(\mathrm{MeS}-\mathrm{tzdt})_{2}\right]$ and $\left[\mathrm{Ni}(\mathrm{EtS}-\mathrm{tzdt})_{2}\right]$. See Table S2 in ESI for calculated $\beta$ values

With one single molecular orientation in a single slab, calculated band structures of both compounds are characterized by one single HOMO band (valence band) and one single LUMO band (conduction band). The smallest direct gap differs however in both compounds, from $0.57 \mathrm{eV}$ in $\left[\mathrm{Ni}(\mathrm{MeS}-\mathrm{tzdt})_{2}\right]$ down to $0.30 \mathrm{eV}$ in $\left[\mathrm{Ni}(\mathrm{EtS}-\mathrm{tzdt})_{2}\right]$ (Fig. 8) in agreement with transport measurements which shows an higher conductivity in the ethyl derivative $\left[\mathrm{Ni}(\mathrm{EtS}-\mathrm{tzdt})_{2}\right]$. It is also anticipated that [Ni(EtS-tzdt $\left.)_{2}\right]$ which exhibits the smallest gap could eventually exhibit a metallic state under very high pressure.

(a) $\mathrm{R}=\mathrm{Me}$

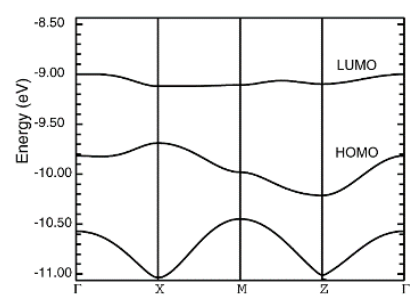

(b) $\mathrm{R}=\mathrm{Et}$

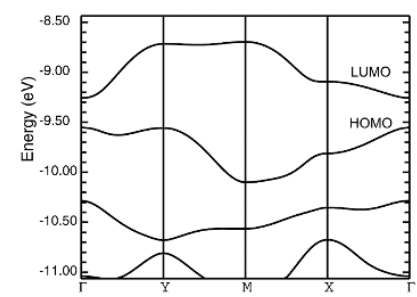


Fig. 8 Calculated band structure for (a) $\left[\mathrm{Ni}(\mathrm{MeS} \text {-tzdt })_{2}\right]$ and (b) $\left[\mathrm{Ni}(\mathrm{EtS}-\mathrm{tzdt})_{2}\right] . \Gamma=(0,0,0), \mathrm{X}=(1 / 2,0$, $0), Y=(0,1 / 2,0), Z=(0,0,1 / 2), M=(1 / 2,1 / 2,0)$ in units of the triclinic reciprocal lattice vectors.

It is also of interest at this stage to compare the solid state organization of these neutral, closed-shell, nickel complex with their analogous, but radical, gold complexes described earlier. Only the ethyl complex $\left[\mathrm{Au}(\mathrm{EtS}-\mathrm{tzdt})_{2}\right]^{\bullet}$ was reported, and its solid state organization strongly differs from the closed-shell nickel complex reported here. Indeed, the radical complexes organize into face-to-face, almost eclipsed dimers (Fig. 9b), while the [Ni(EtS-tzdt)2] complexes described here form regular stacks with much weaker intermolecular interactions (Fig. 9a). Both the nickel and gold complexes are located on inversion centers, allowing us to exclude a possible charge dissymmetry to explain here the different solid state structures, as observed elsewhere. ${ }^{17}$ They actually find their origin in the added overlap interaction of the open-shell radical gold species toward the formation of a $2 \mathrm{e}-$ delocalized bond in the almost eclipsed dimer, a general trend observed recurrently when steric constraints do not hinder this face-to-face overlap. ${ }^{10,18}$ The closed-shell nature of the nickel complexes does not favor such eclipsed overlap.

(a)

(a)

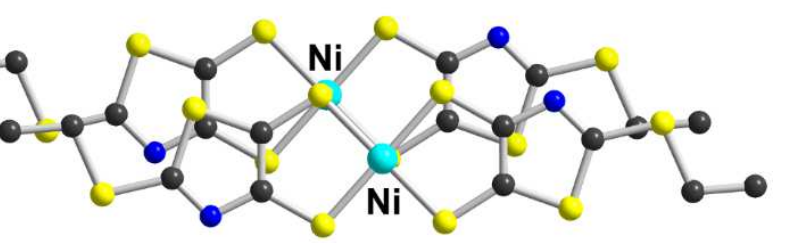

(b)

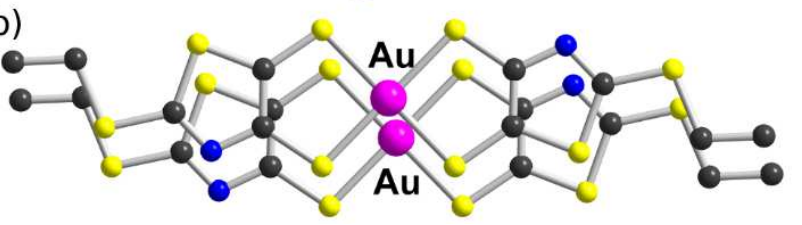

Fig. 9 Comparison of the overlap pattern of (a) the closed-shell $\left[\mathrm{Ni}(\mathrm{EtS}-\mathrm{tzdt})_{2}\right]^{0}$, and (b) the radical [Au(EtS-tzdt)2]' complexes.

\section{Conclusions}

Neutral nickel bis(dithiolene) complexes, because of their closed-shell character, are usually behaving as insulating materials, unless they are formed out of highly delocalized tetrathiafulvalene-dithiolate ligands. We have described here an original series of S-alkyl substituted neutral bis(thiazole-4,5-dithiolate) nickel complexes formulated as $\left[\mathrm{Ni}(\mathrm{RS}-\mathrm{tzdt})_{2}\right]^{0}$ $(\mathrm{R}=\mathrm{Me}, \mathrm{Et})$. We have shown that, besides the usual synthetic route involving the oxidation (electrocrystallization) of the corresponding monoanionic complexes, these neutral complexes 
can be also obtained directly from the transformation of another dithiolene complex, namely the $\mathrm{N}$-tert-butyl-1,3-thiazoline-2-thione-dithiolate $\left[\mathrm{Ni}(\mathrm{tBu} \text {-thiazdt })_{2}\right]^{1-}$ complex in the presence of methyl iodide. The neutral $\left[\mathrm{Ni}(\mathrm{RS}-\mathrm{tzdt})_{2}\right]^{0}(\mathrm{R}=\mathrm{Me}, \mathrm{Et})$ complexes organize in the solid state into non-dimerized, uniform stacks with an overlap pattern which differs strongly from the eclipsed pattern observed in the corresponding neutral but open-shell gold complexes. Despite limited intermolecular interactions, they exhibit a semiconducting behavior, with room temperature conductivities $\left(10^{-4}-10^{-5} \mathrm{~S} \mathrm{~cm}^{-1}\right)$ well above those of most insulating neutral nickel complexes, and close to those reported recently in $\left[\mathrm{Ni}(\mathrm{dmit})_{2}\right]$ and [Ni(Et-thiazdt $)_{2}$ ] complexes $\left(10^{-2}-10^{-3} \mathrm{~S} \mathrm{~cm}^{-1}\right)$. These findings provide new perspectives in the current search for single component molecular conductors as the easy functionalization of the exocyclic sulfur atom in the RS-tzdt ligand opens many opportunities to control the solid state organization of the complexes, taking advantage of crystal engineering strategies explored in dithiolene chemistry such as hydrogen bonding, ${ }^{19}$ introduction of chirality ${ }^{17}$ or soft matter approaches toward discotic phases. ${ }^{11 \mathrm{a}}$

\section{Experimental}

All reagents are commercially available and were used without further purification. Melting points were measured on a Kofler hot-stage apparatus and are uncorrected. Mass spectra were recorded by the Centre Régional de Mesures Physiques de l'Ouest, Rennes. All the reactions were performed under an argon atmosphere. Methanol, acetonitrile and dichloromethane were dried using Inert pure solvent column device. Cyclic voltammetry were carried out on a $10^{-3}$ M solution of complexes $\left[\mathrm{Ph}_{4} \mathrm{P}\right]\left[\mathrm{Ni}(\mathrm{tBu}-\text { thiazdt })_{2}\right]$ and $\left[\mathrm{Ph}{ }_{4} \mathrm{P}\right]\left[\mathrm{Ni}(\mathrm{RS}-\mathrm{tzdt})_{2}\right](\mathrm{R}=\mathrm{Me}, \mathrm{Et})$ in $\mathrm{CH}_{2} \mathrm{Cl}_{2}$ with $\mathrm{NBu}_{4} \mathrm{PF}_{6} 0.1 \mathrm{M}$. Voltammograms were recorded at $0.1 \mathrm{Vs}^{-1}$ on a platinum disk electrode. The potentials were measured versus Saturated Calomel Electrode (SCE). The spectroelectrochemical setup was performed in $\mathrm{CH}_{2} \mathrm{Cl}_{2}$ with $\mathrm{NBu}_{4} \mathrm{PF}_{6} 0.2 \mathrm{M}$ using a Pt grid as the working electrode, a Pt wire as the counter electrode and SCE reference electrode. A Shimatzu 3600 spectrophotometer was employed to record the UV-vis-NIR spectra. The proligands $\mathbf{1}, \mathbf{2 a}$ and $\mathbf{2 b}$ were prepared as previously reported. ${ }^{12}$

\section{Syntheses}

$\left[\mathrm{Ph}_{4} \mathrm{P}\right]\left[\mathrm{Ni}(\mathrm{RS} \text {-tzdt)})_{2}\right]$ (route a). A solution of $\mathrm{Na}(44 \mathrm{mg}, 1.9 \mathrm{mmol})$ in $\mathrm{MeOH}(20 \mathrm{~mL})$ was added to the dithiole-2-one 2 (100 $\mathrm{mg}, 0.45 \mathrm{mmol}$ for $\mathbf{2 a}$ and $106 \mathrm{mg}$ for $\mathbf{2 b}$ ). After complete dissolution the solution was stirred for $30 \mathrm{mn}$ at room temperature. Then a solution of 
$\mathrm{NiCl}_{2} \cdot 6 \mathrm{H}_{2} \mathrm{O}(0.22 \mathrm{mmol}, 54 \mathrm{mg})$ in $\mathrm{MeOH}(5 \mathrm{~mL})$ was added followed 6 hours later by the addition of a solution of $\mathrm{Ph}_{4} \mathrm{PBr}(190 \mathrm{mg}, 0.45 \mathrm{mmol})$ in $\mathrm{MeOH}(5 \mathrm{~mL})$. After stirring for 15 $\mathrm{h}$, the dark precipitate was filtered and recrystallized from $\mathrm{CH}_{2} \mathrm{Cl}_{2} / \mathrm{MeOH}$ (40/60) for $\left[\mathrm{Ph}_{4} \mathrm{P}\right]\left[\mathrm{Ni}(\mathrm{MeS}-\mathrm{tzdt})_{2}\right]$ and from warm $\mathrm{CH}_{3} \mathrm{CN}$ for $\left[\mathrm{Ph}_{4} \mathrm{P}\right]\left[\mathrm{Ni}(\mathrm{EtS}-\mathrm{tzdt})_{2}\right]$ to afford the monoanionic salts as dark blue green crystals.

$\left[\mathrm{Ph}_{4} \mathrm{P}\right]\left[\mathrm{Ni}(\mathrm{MeS}-\mathrm{tzdt})_{2}\right]$ Yield: $31 \%(55 \mathrm{mg}) . \mathrm{Mp}=240^{\circ} \mathrm{C}$. HRMS (ESI) Calcd for $\left[\mathrm{A}^{-}\right]$ C8H6N2S8Ni: 443.76557 Found: 443.7657. Anal. Calcd. for $\mathrm{C}_{32} \mathrm{H}_{26} \mathrm{~N}_{2} \mathrm{NiPS}_{8}$ : C, 48.98; $\mathrm{H}$, 3.34; N, 3.57; S, 32.68. Found: C, 48.90; H, 3.23; N, 3.51; S, 32.34.

$\left[\mathrm{Ph}_{4} \mathrm{P}\right]\left[\mathrm{Ni}(\text { EtS-tzdt })_{2}\right]$ Yield: $62 \%(110 \mathrm{mg}) . \mathrm{Mp}=178^{\circ} \mathrm{C}$. HRMS (ESI) Calcd for [A $\left.{ }^{-}\right]$ C10H10N2S8Ni: 471.7968 Found: 471.7969. Anal. Calcd. for $\mathrm{C}_{34} \mathrm{H}_{30} \mathrm{~N}_{2} \mathrm{NiPS}_{8}$ : C, 50.24; $\mathrm{H}$, $3.72 ; \mathrm{N}, 3.45 \%$. Found: C, 50.62; H, 3.41; N, 3.53\%.

$\left[\mathrm{Ph}_{4} \mathrm{P}\right]\left[\mathrm{Ni}(\mathrm{tBu}-\text { thiazdt })_{2}\right]$. A solution of $\mathrm{Na}(80 \mathrm{mg}, 3.47 \mathrm{mmol})$ in $\mathrm{MeOH}(20 \mathrm{~mL})$ was added to the dithiole-2-one 1 (300 $\mathrm{mg}, 1.14 \mathrm{mmol})$. After complete dissolution the solution was stirred for $30 \mathrm{mn}$ at room temperature. Then a solution of $\mathrm{NiCl}_{2} .6 \mathrm{H}_{2} \mathrm{O}(135 \mathrm{mg}, 0.57 \mathrm{mmol})$ in $\mathrm{MeOH}(5 \mathrm{~mL})$ was added followed 6 hours later by the addition of a solution of $\mathrm{Ph}_{4} \mathrm{PBr}(480$ $\mathrm{mg}, 1.14 \mathrm{mmol}$ ). After stirring for $15 \mathrm{~h}$, the dark precipitate was filtered and recrystallized from $\mathrm{CH}_{2} \mathrm{Cl}_{2} / \mathrm{MeOH}$ (20/80) to afford monoanion $\left[\mathrm{Ph}{ }_{4} \mathrm{P}\right]\left[\mathrm{Ni}(\mathrm{tBu} \text {-thiazdt })_{2}\right]$ as dark red

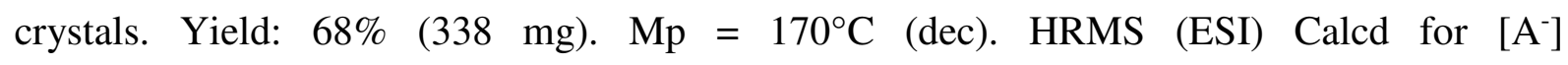
$\left(\mathrm{C}_{14} \mathrm{H}_{18} \mathrm{~N}_{2} \mathrm{~S}_{8}{ }^{58} \mathrm{Ni}\right)$ : 527.85947 Found: 527.8598. Anal. Calcd. for $\mathrm{C}_{38} \mathrm{H}_{38} \mathrm{~N}_{2} \mathrm{PNiS}$ : C, 52.23; H, 4.41; N, 3.22. Found: C, 51.75; H, 4.75; N, 3.05. Crystals of the $\left[\mathrm{PPh}_{4}\right]\left[\mathrm{Ni}(t \mathrm{Bu} \text {-thiazdt })_{2}\right]$ as toluene solvate were obtained through recrystallisation in $\mathrm{CH}_{3} \mathrm{CN} / \mathrm{C}_{6} \mathrm{H}_{5} \mathrm{CH}_{3}(50 / 50)$.

[Ni(RS-tzdt) $)_{2}$ (route b) $\left[\mathrm{PPh}_{4}\right]\left[\mathrm{Ni}(t \text { Bu-thiazdt })_{2}\right](20 \mathrm{mg}, 0.023 \mathrm{mmol})$ was dissolved in 10 $\mathrm{mL}$ of $\mathrm{CH}_{2} \mathrm{Cl}_{2}$. An excess of alkyliodide ( $1 \mathrm{~mL}, \mathrm{CH}_{3} \mathrm{I}$ or $\left.\mathrm{CH}_{3} \mathrm{CH}_{2} \mathrm{I}\right)$ was added to the reaction medium and the solution was refluxed for $2 \mathrm{~h}$ under inert atmosphere. After cooling, a dark blue-greenish precipitate was formed. The solid was filtered and washed with dichloromethane affording the neutral $\left[\mathrm{Ni}(\mathrm{MeS}-\mathrm{tzdt})_{2}\right]$ complex in $64 \%$ yield and neutral $\left[\mathrm{Ni}(\mathrm{EtS} \text {-tzdt })_{2}\right]$ complex in $5 \%$ yield.

\section{Electrocrystallizations}

They were performed in two-compartment cells with Pt electrodes (length $1 \mathrm{~cm}$, diameter 1 $\mathrm{mm})$. $\left[\mathrm{Ni}(\mathrm{MeS}-\mathrm{tzdt})_{2}\right]^{0}$ was obtained from the electrocrystallization of $\left[\mathrm{Ph}_{4} \mathrm{P}\right]\left[\mathrm{Ni}(\mathrm{MeS}-\mathrm{tzdt})_{2}\right]$ in $\mathrm{CH}_{3} \mathrm{CN} / \mathrm{CH}_{2} \mathrm{Cl}_{2}(3 / 1)$ at room temperature in the presence of $\mathrm{NBu}_{4} \mathrm{PF}_{6}$ as electrolyte with a 
current of $0.5 \mu \mathrm{A}$. $\left[\mathrm{Ni}(\mathrm{EtS}-\mathrm{tzdt})_{2}\right]^{0}$ was obtained from the electrocrystallization of $\left[\mathrm{Ph}_{4} \mathrm{P}\right]\left[\mathrm{Ni}(\text { EtS-tzdt })_{2}\right]$ in $\mathrm{CH}_{3} \mathrm{CN}$ at $\mathrm{RT}$ in the presence of $\mathrm{NBu}_{4} \mathrm{PF}_{6}$ as supporting electrolyte with a current of $0.2 \mu \mathrm{A}$. Black crystals were harvested on the anode after 5 days. [Ni(MeStzdt) $)_{2}$ ] HRMS (ASAP) Calcd. for $\mathrm{C}_{8} \mathrm{H}_{6} \mathrm{~N}_{2} \mathrm{~S}_{8} \mathrm{Ni}$ : 443.76557 Found: 443.7652. [Ni(EtS-tzdt $)_{2}$ ] HRMS (ASAP) Calcd. for $\mathrm{C}_{10} \mathrm{H}_{10} \mathrm{~N}_{2} \mathrm{~S}_{8} \mathrm{Ni}$ : 471.7968 Found: 471.7973.

\section{X-Ray Crystallography}

Details of the structural analyses for the six compounds are summarized in Table 4. Data collections were performed on an APEXII Bruker-AXS diffractometer equipped with a CCD camera for $[\mathrm{Ph} 4 \mathrm{P}]\left[\mathrm{Ni}(\mathrm{tBu}-\text { thiazdt })_{2}\right]$, its toluene solvate, $\left[\mathrm{Ph}_{4} \mathrm{P}\right]\left[\mathrm{Ni}(\mathrm{MeS}-\mathrm{tzdt})_{2}\right]$ and $[\mathrm{Ni}(\mathrm{MeS}-$ tzdt $\left.)_{2}\right]^{0}$, and on D8 VENTURE Bruker AXS diffractometer for $\left[\mathrm{Ph}_{4} \mathrm{P}\right]\left[\mathrm{Ni}(\mathrm{EtS}-\mathrm{tzdt})_{2}\right]$ and $\left[\mathrm{Ni}(\text { EtS-tzdt })_{2}\right]^{0}$. Structures were solved by direct methods using the SIR97 program, ${ }^{20}$ and then refined with full-matrix least-square methods based on $F^{2}(S H E L X L-97)^{21}$ with the aid of the WINGX program. ${ }^{22}$ All non-hydrogen atoms were refined with anisotropic atomic displacement parameters. $\mathrm{H}$ atoms were finally included in their calculated positions. Details on the refinement of disorder in some structure are given below.

$\left[\mathrm{PPh}_{4}\right]\left[\mathrm{Ni}(\mathrm{tBu}-\text { thiazdt })_{2}\right]$. The terminal thiocarbonyl function was split in two parts, SADI restraints are used to force the $\mathrm{C}=\mathrm{S}, \mathrm{C}-\mathrm{N}$ and $\mathrm{C}-\mathrm{S}$ distances to be equal in the two parts. The thiocarbonyl group in PART 2 was forced to be flat using the FLAT constraint. Atoms in the two part are refined anisotropically using the SIMU restraint.

$\left[\mathrm{PPh}_{4}\right]\left[\mathrm{Ni}(\mathrm{tBu}-\text { thiazdt })_{2}\right]$ (toluene). The toluene molecule was found disordered on an inversion center. The PART -1 instruction was used to avoid bonding between the two parts across the inversion center. The geometry of the aromatic ring was fixed using the AFIX 66 rigid group constraint. All the carbon atoms of the toluene molecule are refined anisotropically using SIMU and DELU restraints.

$\left[\mathrm{PPh}_{4}\right]\left[\mathrm{Ni}(\text { EtS-tzdt })_{2}\right]$. Disorder was found on the terminal thioethyl group of [Ni(EtS-tzdt $\left.)_{2}\right]$ and on the phenyl rings of the tetraphenylphosphonium cation. The ethyl group was split in two parts using PART -1 and Part -2 instruction to avoid bonding with symmetry generated molecules across the 2 fold axis. Occupation factor was fixed to 0.5 for symmetry reasons. Each phenyl ring of the tetraphenylphosphonium cation was split into two parts, the geometry of the benzene ring was fixed using the AFIX 66 rigid group constraint to avoid large distribution in the $\mathrm{C}-\mathrm{C}$ bond lengths. All the carbon atoms of the aromatic rings are refined anisotropically using SIMU and DELU restraints. Phosphorus-carbon distances are fixed to be equal in each part using the SAME restraint. Occupation factors are fixed to 0.5. 
Table 4 Crystallographic data

\begin{tabular}{|c|c|c|c|c|c|c|}
\hline & \multirow{2}{*}{$\begin{array}{l}{\left[\mathrm{Ph}_{4} \mathrm{P}\right]} \\
{\left[\mathrm{Ni}(\mathrm{tBu}-\text { thiazdt })_{2}\right]}\end{array}$} & \multirow{2}{*}{$\begin{array}{l}\mathrm{C}_{6} \mathrm{H}_{5} \mathrm{CH}_{3} \cdot\left[\mathrm{Ph}_{4} \mathrm{P}\right] \\
{\left[\mathrm{Ni}(\mathrm{tBu} \text {-thiazdt })_{2}\right]}\end{array}$} & \multirow{2}{*}{$\begin{array}{l}{\left[\mathrm{Ph}_{4} \mathrm{P}\right]} \\
{\left[\mathrm{Ni}(\mathrm{MeS}-\mathrm{tzdt})_{2}\right]}\end{array}$} & \multirow{2}{*}{$\begin{array}{l}{\left[\mathrm{Ph}_{4} \mathrm{P}\right]} \\
{\left[\mathrm{Ni}(\mathrm{EtS}-\mathrm{tzdt})_{2}\right]}\end{array}$} & \multirow[t]{2}{*}[\mathrm{Ni}(\mathrm{MeS}\text{-tzdt})_{2}]{} & \multirow[t]{2}{*}[\mathrm{Ni}(\text{EtS-tzdt})_{2}]{} \\
\hline & & & & & & \\
\hline $\mathrm{CCDC}$ & 1826890 & 1826892 & 1826891 & 1826893 & 1826889 & 1826894 \\
\hline Formulae & $\mathrm{C}_{38} \mathrm{H}_{38} \mathrm{~N}_{2} \mathrm{NiPS}_{8}$ & $\mathrm{C}_{45} \mathrm{H}_{46} \mathrm{~N}_{2} \mathrm{NiPS}_{8}$ & $\mathrm{C}_{32} \mathrm{H}_{26} \mathrm{~N}_{2} \mathrm{NiPS}_{8}$ & $\mathrm{C}_{34} \mathrm{H}_{30} \mathrm{~N}_{2} \mathrm{NiPS}_{8}$ & $\mathrm{C}_{8} \mathrm{H}_{6} \mathrm{~N}_{2} \mathrm{NiS}_{8}$ & $\mathrm{C}_{10} \mathrm{H}_{10} \mathrm{~N}_{2} \mathrm{NiS}_{8}$ \\
\hline Crystal size & $0.16 \times 0.12 \times 0.03$ & $0.25 \times 0.23 \times 0.02$ & $0.12 \times 0.10 \times 0.02$ & $0.45 \times 0.23 \times 0.10$ & $0.21 \times 0.11 \times 0.04$ & $0.15 \times 0.08 \times 0.015$ \\
\hline $\mathrm{FW}\left(\mathrm{g} \cdot \mathrm{mol}^{-1}\right)$ & 868.86 & 960.98 & 784.69 & 812.76 & 445.34 & 473.39 \\
\hline System & monoclinic & monoclinic & monoclinic & monoclinic & monoclinic & triclinic \\
\hline Space group & $\mathrm{C} 2 / \mathrm{c}$ & $\mathrm{C} 2 / \mathrm{c}$ & $\mathrm{C} 2 / \mathrm{c}$ & $\mathrm{C} 2 / \mathrm{c}$ & $\mathrm{P} 2{ }_{1} / \mathrm{n}$ & P-1 \\
\hline$a(\AA)$ & $28.7636(17)$ & $26.0877(11)$ & $16.777(3)$ & $19.574(3)$ & $5.0234(9)$ & $6.6193(6)$ \\
\hline $\mathrm{b}(\AA)$ & $7.3314(5)$ & $7.5048(3)$ & $7.5023(12)$ & $18.701(2)$ & $21.360(4)$ & $4.0075(4)$ \\
\hline$c(\AA)$ & $23.4795(14)$ & $24.9380(10)$ & $27.660(4)$ & $9.9430(15)$ & $7.1729(14)$ & $15.4038(14)$ \\
\hline$\alpha(\operatorname{deg})$ & 90.0 & 90.0 & 90.0 & 90.0 & 90.0 & $101.262(3)$ \\
\hline$\beta(\operatorname{deg})$ & $124.372(4)$ & $113.474(2)$ & $105.497(8)$ & $103.080(6)$ & $106.652(5)$ & $87.941(3)$ \\
\hline$\gamma(\operatorname{deg})$ & 90.0 & 90.0 & 90.0 & 90.0 & 90.0 & $91.618(3)$ \\
\hline $\mathrm{V}\left(\AA^{3}\right)$ & $4086.7(5)$ & $4478.4(3)$ & $3354.9(9)$ & $3545.3(9)$ & $737.4(2)$ & $400.39(7)$ \\
\hline $\mathrm{T}(\mathrm{K})$ & $296(2)$ & $296(2)$ & $296(2)$ & $150(2)$ & $296(2)$ & $150(2)$ \\
\hline $\mathrm{Z}$ & 4 & 4 & 4 & 4 & 2 & 1 \\
\hline$D_{\text {calc }}\left(\mathrm{g} \cdot \mathrm{cm}^{-1}\right)$ & 1.412 & 1.425 & 1.554 & 1.523 & 2.006 & 1.963 \\
\hline$\mu\left(\mathrm{mm}^{-1}\right)$ & 0.953 & 0.877 & 1.152 & 1.093 & 2.431 & 2.244 \\
\hline Total refls & 17557 & 13922 & 12617 & 12716 & 4945 & 4642 \\
\hline Abs. corr. & multi-scan & multi-scan & multi-scan & multi-scan & multi-scan & multi-scan \\
\hline $\mathrm{T}_{\min }, \mathrm{T}_{\max }$ & $0.872,0.972$ & $0.803,0.983$ & $0.871,0.977$ & $0.639,0.896$ & $0.733,0.907$ & $0.714,0.967$ \\
\hline Uniq refls & 6172 & 5122 & 3860 & 4082 & 1690 & 1827 \\
\hline $\mathrm{R}_{\text {int }}$ & 0.0451 & 0.0359 & 0.0344 & 0.0542 & 0.0855 & 0.0157 \\
\hline $\begin{array}{l}\text { Uniq refls } \\
(\mathrm{I}>2 \sigma(\mathrm{I}))\end{array}$ & 3812 & 3447 & 2803 & 3501 & 965 & 1700 \\
\hline $\mathrm{Nb}$ param. & 251 & 282 & 202 & 290 & 89 & 98 \\
\hline $\mathrm{R}_{1}(\mathrm{I}>2 \sigma(\mathrm{I}))$ & 0.066 & 0.0488 & 0.0377 & 0.0563 & 0.0553 & 0.0190 \\
\hline$w_{2}$ (all data) & 0.2128 & 0.1361 & 0.0925 & 0.1431 & 0.1165 & 0.0768 \\
\hline GOF & 1.031 & 1.016 & 1.027 & 1.049 & 0.97 & 1.288 \\
\hline $\begin{array}{l}\text { Res. Dens. } \\
\left(\mathrm{e} \AA^{-3}\right)\end{array}$ & $1.277,-1.039$ & $0.547,-0.654$ & $0.33,-0.26$ & $1.174,-1.763$ & $0.67,-0.51$ & $0.476,-0.581$ \\
\hline
\end{tabular}

\section{Theoretical calculations}

The orbital calculations, tight-binding band structure calculations and $\beta$ interaction energies were based upon the effective one-electron Hamiltonian of the extended Hückel method, ${ }^{23}$ as implemented in the Caesar 1.0 chain of programs. ${ }^{24}$ The off-diagonal matrix elements of the Hamiltonian were calculated according to the modified Wolfsberg-Helmholz formula. ${ }^{25}$ All 
valence electrons were explicitly taken into account in the calculations and the basis set consisted of double- $\zeta$ Slater-type orbitals for all atoms except $H$ (single- $\zeta$ ). The exponents, contraction coefficients, and atomic parameters for $\mathrm{Ni}, \mathrm{C}, \mathrm{S}, \mathrm{N}$ and $\mathrm{H}$ were taken from previous work. ${ }^{10,26}$

Resistivity measurements. The resistivity measurements were performed along the long axis of the platelet-shaped crystals ( $a$ crystallographic axis for [Ni(MeS-tzdt) $)_{2}$, $b$ crystallographic axis for $\left[\mathrm{Ni}(\mathrm{EtS}-\mathrm{tzdt})_{2}\right]$. Measurements were performed either with gold pads made by Joule evaporation on both ends of the crystals with gold wires glued with silver paste on those contacts, or with gold wires directly glued with silver paste on the crystals. Because of their high values (>10 M $\Omega$ ), the resistance of the crystals was measured in two points applying a constant voltage $(1$ or $2 \mathrm{~V})$ and measuring the current with a Keithley 6486 picoammeter / voltage source. Low temperature was provided by a homemade cryostat equipped with a $4 \mathrm{~K}$ pulse-tube.

Magnetic measurements and modelisation The magnetic susceptibility measurements were obtained from a Quantum Design SQUID magnetometer MPMS-XL. This magnetometer works between 1.8 and $400 \mathrm{~K}$ for dc applied fields ranging from -5 to $5 \mathrm{~T}$. Measurements were performed on polycrystalline samples of $\left[\mathrm{PPh}_{4}\right]\left[\mathrm{Ni}(t \mathrm{Bu} \text {-thiazdt })_{2}\right](12.1 \mathrm{mg}$ at $5000 \mathrm{G})$, $\left[\mathrm{Ph}_{4} \mathrm{P}\right]\left[\mathrm{Ni}(\mathrm{MeS}-\mathrm{tzdt})_{2}\right],(9.7 \mathrm{mg}$ at $2000 \mathrm{G})$ and $\left[\mathrm{Ph}_{4} \mathrm{P}\right]\left[\mathrm{Ni}(\mathrm{EtS}-\mathrm{tzdt})_{2}\right](6.5 \mathrm{mg}$ at $10000 \mathrm{G})$. The magnetic data were corrected for the sample holder and the diamagnetic contributions.

\section{Conflicts of interest}

There are no conflicts to declare.

\section{Acknowledgements}

We thank V. Dorcet and T. Roisnel (CDIFX, ISCR, Rennes) for the X-ray crystal structures of $\left[\mathrm{Ph}_{4} \mathrm{P}\right]\left[\mathrm{Ni}(\mathrm{EtS}-\mathrm{tzdt})_{2}\right]$ and $\left[\mathrm{Ni}(\mathrm{EtS}-\mathrm{tzdt})_{2}\right]$. 


\section{References}

${ }^{1}$ (a) R. Kato, Bull. Chem. Soc. Jpn., 2014, 87, 355-374; (b) R. Kato, Chem. Rev., 2004, 104, $5319-5346$.

${ }^{2}$ Dithiolene Chemistry, Prog. Inorg. Chem., E. I. Stiefel Ed. 2004, vol. 52.

${ }^{3}$ (a) E. Canadell, S. Ravy, J.-P. Pouget and L. Brossard, Solid State Commun., 1990, 633638; (b) W. Kaddour, P. Auban-Senzier, H. Raffy, M. Monteverde, J.-P. Pouget, C. R. Pasquier, P. Alemany, E. Canadell and L. Valade, Phys. Rev. B, 2014, 90, 205132.

4 (a) T. Kambe, R. Sakamoto, K. Hoshiko, K. Takada, M. Miyachi, J.-H. Ryu, S. Sasaki, J. Kim, K. Nakazato, M. Takata and H. Nishihara, J. Am. Chem. Soc., 2013, 135, 2462-2465; (b) T. Kambe, R. Sakamoto, T. Kusamoto, T. Pal, N. Fukui, K. Hoshiko, T. Shimojima, Z. Wang, T. Hirahara, K. Ishizaka, S. Hasegawa, F. Liu and H. Nishihara, J. Am. Chem. Soc., 2014, 136, 14357-14360.

5 B. Garreau-de Bonneval, K. I. Moineau-Chane Ching, F. Alary, T.-T. Bui and L. Valade, Coord. Chem. Rev., 2010, 254, 1457-1467.

6 (a) H.-B. Cui, H. Kobayashi, S. Ishibashi, M. Sasa, F. Iwase, R. Kato and A. Kobayashi, J. Am. Chem. Soc., 2014, 136, 7619-7622; (b) H.-B. Cui, J. S. Brooks, A. Kobayashi, and H. Kobayashi, J. Am. Chem. Soc., 2009, 131, 6358-6359; (c) A. Kobayashi, B. Zhou and H. Kobayashi, J. Mater. Chem., 2005, 15, 3449-3451; (d) E. Fujiwara, A. Kobayashi, H. Fujiwara and H. Kobayashi, Inorg. Chem., 2004, 43, 1122-1129; (e) H. Tanaka, Y. Okano, H. Kobayashi, W. Suzuki and A. Kobayashi, Science, 2001, 291, 285-287; (f) A. Kobayashi, H. Tanaka, M. Kumasaki, H. Torii, B. Narymbetov and T. Adachi, J. Am. Chem. Soc., 1999, 121, 10763-10771.

7 (a) H. Alves, A. I. S. Neves, W. Gouveia, R. A. L. Silva and D. Belo, Chem. Commun., 2015, 51, 12117-13119; (b) J. P. M. Nunes, M. J. Fugueira, D. Belo, I. C. Santos, B. Ribeiro, E. B. Lopes, R. T. Henriques, J. Vidal-Gancedo, J. Veciana, C. Rovira and M. Almeida, Chem. Eur. J., 2007, 13, 9841-9849.

8 I. Malfant, K. Rivasseau, J. Fraxedas, C. Faulmann, D. De Caro, L. Valade, L. Kaboub, J.M. Fabre and F. Senocq, J. Am. Chem. Soc., 2006, 128, 5612-5613.

9 (a) L. Valade, J.-P. Legros, M. Bousseau, P. Cassoux, M. Garbauskas and L. V. Interrante, J. Chem. Soc. Dalton Trans., 1985, 783-794; (b) H.-B. Cui, T. Tsumuraya, T. Miyazaki, Y. Okano and R. Kato, Eur. J. Inorg. Chem., 2014, 24, 3837-3840.

10 A. Filatre-Furcate, N. Bellec, O. Jeannin, P. Auban-Senzier, M. Fourmigué, A. Vacher and D. Lorcy, Inorg. Chem., 2014, 53, 8681-8690. 
${ }^{11}$ (a) K. Mebrouk, W. Kaddour, P. Auban-Senzier, C. Pasquier, O. Jeannin, F. Camerel, and M. Fourmigué, Inorg. Chem., 2015, 54, 7454-7460. (b) S. Rabaça, A. C. Cerdeira, S. Oliveira, I. C. Santos, R. T. Henriques, L. C. J. Pereira, J. T. Coutinho and M. Almeida Polyhedron, 2012, 39, 91-98.

12 (a) A. Filatre-Furcate, P. Auban-Senzier, M. Fourmigué, T. Roisnel, V. Dorcet and D. Lorcy, Dalton Trans., 2015, 44, 15683-15689; (b) A. Filatre-Furcate, T. Roisnel and D. Lorcy, J. Organomet. Chem., 2016, 819, 182-188.

${ }^{13}$ V. Hernandez, C. Castiglioni, M. Del Zoppo, and G. Zerbi, Phys. Rev. B, 1994, 50, 98159823.

14 (a) Y. Le Gal, A. Vacher, V. Dorcet, M. Fourmigué, J. Crassous and D. Lorcy, New J. Chem., 2015, 39, 122-129; (b) S. Eid, M. Fourmigué, T. Roisnel and D. Lorcy, Inorg. Chem., 2007, 46, 10647-10654.

15 (a) J. C. Bonner and M. E. Fisher, Phys. Rev. A, 1964, 135, 640; (b) W. E. Hatfield, J. Appl. Phys., 1981, 52, 1985-1990; (c) W. E. Estes, D. P. Gavel, W. E. Hatfield and D. Hodgson, Inorg. Chem., 1978, 17, 1415-1421.

${ }^{16}$ N. S. Kini, E. E. Kaul and C. Geibel, J. Phys.: Cond. Matter, 2006, 18, 1303-1311.

17 D. G. Branzea, F. Pop, P. Auban-Senzier, R. Clérac, P. Alemany, E. Canadell and N. Avarvari, J. Am. Chem. Soc., 2016, 138, 6838-6851.

${ }^{18}$ M. Fourmigué, in The Importance of $\pi$-Interactions in Crystal Engineering: Frontiers in Crystal Engineering $2^{\text {nd }}$ Edition, E. Tiekink and J. Zukerman-Schpector Eds., John Wiley \& Sons Ltd, 2012, Chp 6, pp. 143-162.

${ }^{19}$ (a) T. Bsaibess, M. Guerro, Y. Le Gal, D. Sarraf, N. Bellec, M. Fourmigué, F. Barrière, V. Dorcet, T. Guizouarn, T. Roisnel and D. Lorcy, Inorg. Chem., 2013, 52, 2162-2173; (b) Y. Le Gal, T. Roisnel, P. Auban-Senzier, T. Guizouarn and D. Lorcy, Inorg. Chem., 2014, 53, $8755-8761$.

${ }^{20}$ A. Altomare, M. C. Burla, M. Camalli, G. Cascarano, C. Giacovazzo, A. Guagliardi, A. G. G. Moliterni, G. Polidori and R. Spagna, J. Appl. Cryst., 1999, 32, 115-119.

${ }^{21}$ G. M. Sheldrick, Acta Crystallogr., 2008, A64, 112-122.

${ }^{22}$ L. J. Farrugia, J. Appl. Cryst., 2012, 45, 849-854.

${ }^{23}$ M.-H. Whangbo and R. Hoffmann, J. Am. Chem. Soc., 1978, 100, 6093-6098.

${ }^{24}$ J. Ren, W. Liang and M.-H Whangbo, Crystal and Electronic Structure Analysis Using CAESAR, PrimeColor Software Inc., Cary (NC) USA, 1998 
25 J. Ammeter, H.-B. Bürgi, J. Thibeault and R. Hoffmann, J. Am. Chem. Soc., 1978, 100, 3686-3692.

${ }^{26}$ B. Domercq, T. Devic, M. Fourmigué, P. Auban-Senzier and E. Canadell, J. Mater. Chem. 2001, 11, 1570-1575. 


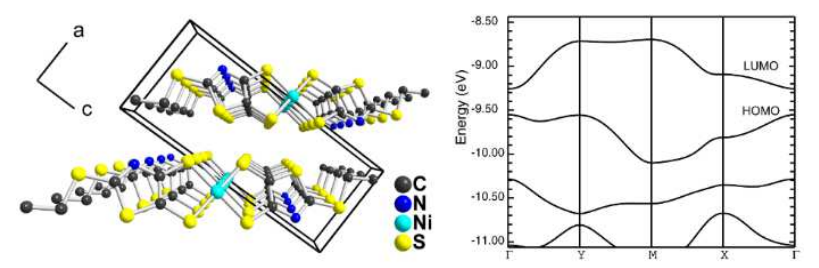

Despite their closed-shell character, neutral bis(thiazole-4,5-dithiolate) nickel dithiolene complexes $\left[\mathrm{Ni}(\mathrm{RS}-\mathrm{tzdt})_{2}\right]^{0}(\mathrm{R}=\mathrm{Me}, \mathrm{Et})$ behave as single component conductors. 